\title{
Semantic Change in Portuguese: Considering Cerrado and Vereda
}

\author{
Daniel Marra ${ }^{a}$ \\ danielmarra@ifto.edu.br \\ Federal Institute of Tocantins, Brazil \\ \& \\ The University of Sydney, Australia (Visiting Scholar) \\ Marie Quinn \\ marie.quinn@uts.edu.au \\ University of Technology Sydney, Australia \\ Luiz Arthur Blamires \\ lablamires@hotmail.com \\ Université de Paris, France (Paris Diderot)
}

\begin{abstract}
This paper highlights the process by which meaning instantiates itself in word formation and discusses how semantic change installs subsequently in them, in this case, the Portuguese words cerrado and vereda. These two words have long individual histories that can be tracked back to their Latin or Celtic etymons, cerrado rooted in the origin of the Latin verb serāre, which gave origin to the Portuguese verb cerrar (to close, to seal) and vereda (narrow path) derived from the Latin word veredus (horse), which has its root in the Celtic word voredos. Yet, in the modern Brazilian context, Cerrado designates a particular ecosystem, the second largest biome in the country, that of short, closely-packed trees and foliage, and Vereda, a verdant subsystem of the same ecosystem. The discussion tracks the linguistic movement to arrive at these current meanings, showing how understanding the "history" of a word helps to understand both the uniqueness of its morpho-phonological and semantic constitution, as well as that of its relationship with the object it designates in the empirical world.
\end{abstract}

Keywords: Semantic Change; Lexicon; Metaphor/Metonymy; Portuguese language

\section{INTRODUCTION}

The current Brazilian Portuguese lexicon is the result of internal and external historical processes that defined the contours of the forms and meanings of their lexical items, and the structure of words "reflects the historical trends of language" (Rio-Torto, 2014, p. 31). Thus, analysis of such forms and meanings unveils their constitutive features and tells the story of their developments, revealing metaphoric meanings that have been lost through naturalized use of the terms. In this case, two terms drawn from Brazilian geography, cerrado and vereda, are analysed to understand how metaphoric meanings established at the time of naming have been lost and reconstituted through the use of modifiers to signify new physical entities.

The lexical item Cerrado designates the second largest Brazilian biome after the Amazon, identified as the oldest of recent environments of planet Earth. The word is currently borrowed as classificatory terminology into English without denotation as a Portuguese word (see, for example, de Sousa, Brasil \& Figueiredo, 2015). Cerrado ${ }^{1}$ vegetation is that which is

a Corresponding author

$b$ Main author

${ }^{1}$ Cerrado and Vereda will not be italicised when used as a geographic classification used in English. They will be capitalised to indicate a proper noun, the name of a biome feature. 
thought to have appeared in the wake of meteor devastation that extinguished almost all living beings that lived in the planet (Barbosa, 2015). It is tropical and covers $21 \%$ of the country's land mass as plateaus of central Brazil. Within this biome is the subsystem Vereda, formed as a result of groundwater protuberance playing a fundamental role in the Cerrado hydrological system (Ribeiro \& Walter, 2008).

However, the Portuguese words from which these are drawn bear little resemblance at first glance to these geographical forms: cerrar (to close, to seal) and vereda (narrow path, route). In the case of vereda, the Latin meaning with Celtic origins (horse) is even more difficult to identify. The new terms have been constituted by metaphor and metonymy, and meanings are no longer perceived without resorting to past synchronies or even to the etymon of the lexical items under analysis. The lexicon is further expanded with the descriptions "sparse cerrado" and "closed cerrado", illustrating how the factors that motivated its creation have been forgotten and the semantic relationship between the designation and its meaning is lost.

To explore how these geographic words have been created metaphorically and continue to be re-defined and used in Portuguese and, indeed, in other languages, this paper will consider how lexicons are formed and expanded, particularly through the use of metaphor and metonymy in labeling new entities, and how these words have entered and been changed through use in the Brazilian and scientific community. Such analysis adds to the understanding of how use both shapes and changes meaning.

\section{EXPANDING THE LEXICON THROUGH METAPHOR/METONYMY}

\section{ESTABLISHING A LEXICON}

The acquisition of the lexical inventory of a language by the speaker occurs through their exposure to the signs of that language, through the interaction with individuals that belong to the same speech community, thus, the lexicon available to each individual is representative of the lexicon of the speech community of which they belong. Certainly, the lexical inventory that makes up the repertoire of the speech community is much more numerous than the individual speaker's one, since each speaker acquires in a particular way the lexical items of his language (see, for example, early discussions from Whitney, 1867 in Marra \& Milani, 2013, p. 133). Therefore, the sum of the lexical units available to individual speakers is greater than the one that the individual speaker can embrace. However, every speaker belonging to a linguistic community can interact intelligibly with the other members, since the linguistic inventory of the particular being does not differ substantially from the lexicon that constitutes the repository of the community as a whole. Additionally, and despite the interests of readers of this journal, to function competently and intelligibly, the ordinary speaker does not require the etymological knowledge of the lexical items that compose their language.

Nevertheless, Villalva and Silvestre (2014, p. 25) claim a prominent place for etymological studies, arguing that "o conhecimento de uma dada propriedade das unidades lexicais potencia o conhecimento de outra ou outras das suas propriedades ${ }^{2}$ [the knowledge of a given property of lexical units enhances the knowledge of another, or their other properties]" To this end, historical approaches to the study of language change, and the factors that motivate change, have been for centuries, and continue to be, among the main activities within linguistic

\footnotetext{
${ }^{2}$ The authors recognise and valorise languages other than English in academic discourse and have chosen to render all quotes in the original language with English translations wherever available, following the issues raised in authors such as Curry, M. J., \& Lillis, T. (2004). Multilingual scholars and the imperative to publish in English: Negotiating interests, demands, and rewards. TESOL quarterly, 38(4), 663-688, and considering the work of Santos (Santos, B. D. S., Meneses, M. P. G., \& Nunes, J. A. (2006). Conhecimento e transformação social: por uma ecologia de saberes. Hiléia: revista de direito ambiental da Amazônia, 4(6), 9-103.) in disrupting the hegemony of English. Translations have been provided by the authors.
} 
studies. These studies are exemplified in early work by Schuchardt (1842-1927) who argued that study of a language could not be divorced from time and space (see Viaro, 2011) and by Meillet (1905-1906), demonstrating how the meaning of words depends on the circumstances of their use and change in meaning closely related to the uses that different linguistic groups make of particular words. Labov (1994), lent his voice to the importance of diachronic studies on linguistic change, highlighting the difficulty of unraveling its mysteries: "the existence of language change is among the most stubborn and difficult to assimilate when we try to come to grips with the nature of language in general as it is reflected in the history of a language" ( $p$. 9). More recently, Viaro, Ferreira and Guimarães-Filho (2014) have suggested that

para entender como uma língua funciona é preciso mesclar dados históricos com os elementos presentes da comunicação atual entre os falantes ... uma vez que todos sabemos que a essência das línguas é mutável diacronicamente, como se flagra no intervalo de uma vida [to understand how a language works we need to merge historical data with the present elements of current communication between speakers ...since language is diachronically changeable, as one can see it in the span of a lifetime].

Foregrounding the sociolinguistic relevance of history and use counters Saussure's (2006[1916]) defense of the study of language from a synchronic point of view.

One aspect of lexicon expansion and semantic change that has attracted much interest from sociolinguistic and cognitivists has been the instances of and definition of metaphor and metonymy, particularly - for this paper - how they are applied initially/historically and manner in which meanings change over time and use. The change of meaning of words emerges, in this perspective, through the transposition of a restricted use by a certain linguistic group to a general use, when the word loses the original etymological idea and gains a new meaning, a semasiological change. In this sense, metaphorical terms, quite abundant in the process of lexical creation, will no longer be noted as such when they cease their specialized uses and pass into general use.

\section{METAPHOR AND METONYMY}

Humans use language to represent and reflect their environment, in ways that be called congruent or incongruent: using words that map closely to that being expressed (the big red car) to words that draw on various domains of understanding to make meaning (the mobile petrol guzzler). These latter instances, described by Barcelona (2003, p. 3) as "whereby one experiential domain is partially 'mapped', i.e. projected, onto a different experiential domain, so that the second domain is partially understood in terms of the first one" takes language into the realm of metaphor. For Trask (2011), metaphor refers to the "literal use of a linguistic form, used as a resource to draw attention to perceived similarity" (p. 190-191). He argues that most metaphors are so familiar "that we no longer perceive them as metaphorical". Fiorin (2014) adds that "métafora é uma concentração sêmica" [metaphor is a semantic concentration], that is, a new meaning forming with reference to another meaning that already existed in the language assimilates of the former the semantic traits that will define both.

Metonymy, though related to metaphor by expanding the meaning of words through a process of semantic transfer, establishes a compatibility of meaning by proximity. Fiorin (2014) argues that:

no eixo da extensão, um valor semântico transfere-se para outro, num espalhamento sêmico ... o que estabelece uma compatibiliade entre os dois sentidos é uma contiguidade, ou seja, uma proximidade, uma vizinhança, um contato [on the axis of extension, a semantic value is transferred to another, as in a semantic spread ... What establishes a compatibility between the two meanings is a contiguity, that is, a proximity, a neighborhood, a contact]. (p. 37) 
Separating and defining these two terms have been discussed at length in linguistic research in an effort to distinguish a continuum of use. Radden (2000) offers this definition:

Metonymy is a mapping within the same conceptual domain. Metaphor is a mapping of one conceptual domain into another. Metonymy-based metaphor is the mapping involving two conceptual domains which are grounded in, or can be traced back to, one conceptual domain. [italics in original] (p. 93)

However, in describing the connections between the terms as "slippery", Barnden (2010) questions the drive to define over the exploration of links between meanings, that "considering the dimensions in themselves helps to free us from a mindset that seeks clear-cut differences between metaphor and metonymy when these may not exist." (p. 26). Such a view suggests that seeking to understand how meanings of Portuguese words have changed over time helps us to understand the shifts in meaning and use, provides some insight into how people label and classify their world, rather than engage in defining the linguistic labelling.

Metaphor and metonymy have been used in sociolinguistics to understand changes in society's language norms, for example the use of and racist language (Musolff, 2012) and emergence of emotional language (Díaz-Vera, 2014). However, the study lies more firmly within a cognitive approach, how the mind is making sense of the world through the understanding of metaphoric relationships.

At the heart of cognitive linguistics, Lakoff and Johnson (1980) characterized metaphor and metonymy as the foundation of natural languages' semantics, forming coherent systems through which experience is conceptualized. As constitutive of the way human beings think the world and represent it through language, "metaphor is pervasive in everyday life, not just in language but in thought and action. Our ordinary conceptual system, in terms of which we both think and act, is fundamentally metaphorical in nature" (Lakoff \& Johnson, 1980, p. 3). According to Silva (2006), these concepts traditionally conceived as rhetorical figures have given way, in recent decades, to a reconceptualization. He refers to the importance of Lakoff and Johnson's studies for the understanding of the cognitive:

\footnotetext{
Hoje, sabemos que metáfora e metonímia são fenómenos conceituais por natureza, processos e modelos cognitivos, constitutivos do nosso sistema conceitual, modos naturais de pensar e de falar, tanto na linguagem corrente como no discurso científico, radicados na experiência humana e responsáveis quer pela estruturação do pensamento, da linguagem e da acção, quer pela inovação conceptual.

[Today we know that metaphor and metonymy are conceptual phenomena by nature, cognitive processes and models, constitutive of our conceptual system, natural ways of thinking and speaking, both in everyday language and scientific discourse, rooted in human experience and responsible either for the structuring of thought, language and action, or by conceptual innovation.]

(Silva, 2006, p. 110)
}

Using these understandings of metaphor and metonymy, that they play important roles in the process of lexical creation, the following analysis highlights two lexical items form Brazilian Portuguese, how historical events have worked to change the meanings while retaining the morpho-phonological forms. New geographical realities - the biome found in Brazil - gave rise to the application of words, metaphoric in nature, whose original meanings have shifted to take on new lexical and grammatical forms.

\section{METHOD}

This study follows the methodological perspective of cognitive semantics (Lakoff, 1987; Lakoff and Johnson, 1980) and Silva (2006; 1999), and the diachronic semantic dimension (Viaro, 2011; Roth, 1998). These approaches contribute to lexical studies at the descriptive, 
methodological and theoretical levels. At the descriptive level, it highlights the word's morphophonological structure and its semasiological variable semantic content. At the theoretical level, it stresses the scope of diachronic analysis, showing the internal structure of the words under analysis, their functioning in everyday life, their meaning and their changes of meaning. At the methodological level, it shows the advantages of an analysis based on the history of a language lexicon and on the developments of meaning its words have gone through in past synchronies as well as focused on current language usage, integrating the synchronic and diachronic perspectives. Fundamentally, for the purpose of this paper, the analysis thus uses the semantic theory in its historical or diachronic approach that guides the explanation of the semantic change over time.

\section{DISCUSSION}

\section{CERRADO AND VEREDA, MEANING IN PORTUGUESE}

The two words under discussion - cerrado and vereda - are used in contemporary Portuguese and are derived form Latin and older forms. In tracing the origins of these words, vereda in its contemporary use is already a form of metonymy. Thus, its use in labeling the Brazilian landform is a laying of metaphor, further obscuring the original meanings.

Etymologically, the meaning of the word cerrado is rooted in the origin of the Latin verb serāre, which gave origin to the Portuguese verb cerrar (to close, to seal). The past participle of this verb is used to say that something has been closed (cerrado), in a way that it does not enable passage through it. A contemporary and everyday use of the word might be to say that "A porta foi cerrada" (The door has been closed). In this case, the last vowel 'a' in cerrada means that the word is gender marked, because in Portuguese "porta' (door) is a feminine word. "O livro foi cerrado" (The book has been closed). The letter 'o' in cerrado means that book is a masculine word in Portuguese. (The verb fechar [meaning to close] is more usual in current Portuguese than the verb cerrar.) Note that the word Cerrado that designates an ecosystem is reduced of campos cerrados (closed fields), that was simplified over time in Cerrado only, without reference to the originally gendered forms.

The etymology of the word vereda is more metonymic. In contemporary Portuguese, the term vereda is widely known in Portuguese language as a narrow path (and in a figurative sense as route and direction) and used in a congruent manner in the sentence "Pegue aquela vereda e siga em frente" (Take that route and go ahead) or "Guia-me pelas veredas da justiça" (He guides me along the right paths [Psalm 23:4]). However, the word is derived from the Celtic word voredos for horse. As it moved into Latin as veredus, the word designated a particular type of horse, one that was fast enough to carry messages, a post horse. The term post designated the "posto de parada outrora situado nas estradas, de espaço a espaço, onde se efetuava a muda dos cavalos das diligências e outros veículos, ou do serviço de correio" [stopping place formerly located on the roads, from space to space, where the stagecoach horses and other vehicles were changed, or the mail service] (Ferreira, 2004, p. 2050), from which the term postal originates. In further synchronies, the term veredus was derived by metonymy to name the path taken by the post horses, giving rise to the word vereda.

The example above, shows that there is not a coexistence of identity between the lexical unities veredus and vereda, of course they had different meanings, but it shows that there is a contiguity of meaning, as if the term vereda could evoke the character that defines and specifies the contours of its meaning, the veredus. Thus, vereda would originally designate the route through which the veredus passed. In the instantiation of meaning in this word, here is a process of semic transfer from veredus (specifying agent) to vereda (specified object), but the two items retain their individual identities, just as the words train and rail remain independent terms, 
although one necessarily evokes the existence of the other. This contiguity of meaning allows one to realise a metonymic relationship.

\section{SEMANTIC CHANGE: METAPHORIC USE IN NAMING THE LANDSCAPE}

As Europeans explored and mapped the Brazilian interior between the $16^{\text {th }}$ and $19^{\text {th }}$ centuries, new landscapes and habitats required words that did not already exist. Drawing on Portuguese lexicon, they designated labels that reflected their way of recognizing salient features of the environment, often using metaphoric understandings. As Kos (2019) notes, the ability to use metaphor or metonymy is of practical value "the use of metaphor (and metonymy) enables us to form naming units with greater economy; of course, at the cost of their transparency" (p. 152). Transparency, in this case, is lost when the original meaning is lost.

Early in the nineteenth century, the word cerrado was used by Carl Friedrich Philipp von Martius (1943 [1824]) when addressing the characteristics of Midwestern Brazilian vegetation in passages in which he described its use by the countrymen: "a diferença mais importante é aquela que é designada pelos brasileiros como os nomes de campo limpo e campo fechado, cerrado" [... the most important difference is that which is designated by Brazilians as the names of open-field and closed-field, cerrado] (p. 256) suggesting that it was already in use. It was also used by Eugenius Warning in the late 19th century in his book, Lagoa Santa (Warning, 1973 [1892]), a translation from Danish by Albert Löfgren (1896) where he had used the term in a study of plant distribution in the state of São Paulo. Warning used both the expression campos-cerrados (closed-fields), abbreviated this to cerrado.

The original Portuguese meaning can be traced into the definition presented scientifically. The biome Cerrado is characterized by the phytophysiognomic particularity of its arboreal vegetation, "campo cerrado cujas árvores se acham mais próximas umas das outras" [closed field whose trees are closer to each other] (Ferreira, 2004, p. 443). The naming of the ecosystem is derived from the salient characteristic of its vegetation, the manner in which the crowns of the shorter trees trunks "close" the environment in which they are concentrated, making circulation and passage difficult. The speakers in Midwestern Brazil sought to name a vegetation with a name that could conceptually highlight and describe its visually perceptible traits.

The subsystem Vereda was first described by Martius (1938), named varredas, in his classic text Travel through Brazil 1817-1820. The existence of this phenomena is due to the rising of groundwater into the Cerrado, usually along the riverbanks, fundamental for the "manutenção da fauna do Cerrado, funcionando como local de pouso para a avifauna, atuando como refúgio, abrigo, fonte de alimento e local de reprodução também para a fauna terrestre e aquática" [maintenance of the Cerrado fauna, functioning as a landing site for the avifauna, and acting as a refuge, shelter, food source and breeding site for terrestrial and aquatic fauna] (Ribeiro \& Walter, 2008, p. 183). Ferreira (2004) notes regional differences in the meaning: in Northeastern Brazil, Vereda is a "most abundant water region in the caatinga zone"; in the state of Goiás, it is a "floodplain that borders a river"; and in Minas Gerais, the name Vereda is given to the "headland and watercourse bordered by buritis" (p. 2050). Currently, such regions are under threat from agricultural expansion (de Sousa et al, 2015).

The metaphoric link to the naming of this geographical feature is the manner in which the Vereda makes a path through otherwise difficult and unforgiving vegetation, the Cerrado. In one of the most important epics of Portuguese language literature, Grande Sertão: Veredas [The Great Hinterland: Veredas published in English as The Devil to Pay in the Backlands] (1956), João Guimarães Rosa highlights the hostile environments of the Sertão (dry hinterlands) as opposed to the welcoming environment of the Veredas. Rosa describes the environment to his Italian translator to clarify the environment: 
As veredas são férteis. Cheias de animais, de pássaros... Nas veredas há às vezes grandes matas, comuns. Mas, o centro, o íntimo vivinho e colorido da vereda, é sempre ornado de buritis, buritiranas, safarrás e pindaíbas à beira da água. As veredas são sempre belas! [The veredas are fertile. Filled with animals, birds ... In the veredas there are sometimes large woods, common. But, the center, the lively and colorful core of the vereda, is always adorned with buritis, buritiranas, safarrás and pindaíbas along the water shore. The veredas are always beautiful!]

(Rosa, 2003, p. 37)

This lexical item, vereda, has broadened its specificity and meaning by metaphor: it emphasizes the relationship that exists between a watercourse and the route that it builds through the geographical space, a path built by the force of water because of the moist terrain. This is, certainly, a re-analysis of the lexical item vereda, which gains a new meaning, but maintains a metaphorical intersection with the previous sense, which is narrow path, route.

Thus, both words, cerrado and vereda, have undergone semantic change as they have contributed to the lexicon by providing the means for Portuguese speakers to understand new phenomena, the landscape, and their own relationship with it. Portuguese settlers have experienced the natural world and requisitioned language metaphorically to note the salient features, thereby creating new ways to understand these terms.

\section{SEMANTIC CHANGE: NEW USES EMERGING}

While we have traced the manner in which the Portuguese terms for closed and path have been re-designated to provide the means to understand features of the new environment they were encountering, the new uses have also been semantically and grammatically re-worked into the language. In modifying and re-classifying the terms, the contemporary uses of the words obscure the original meanings further and the lexical items no longer claim the meanings that first designated those objects in the empirical world.

As an example of this semantic shift, Cerrado originally denoted the closed in vegetation of the plateaus, before farming or large-scale human activity was evident. However, according to Ribeiro and Walter (2008), conditioning factors gave origin to three physiognomic subdivisions of Cerrado: the heavy; the typical; and, the sparse Cerrado. Thus, while the original designation was that the source-domain, the lexicographic form cerrado, was the target-domain, this vegetation (CERRADO IS THIS VEGETATION), the ways of observing and classifying the vegetation - conceivably through human activity on the vegetation, has resulted in the semantic relationship between the designation and its meaning is lost.

More interesting in terms of lexical expansion, the Cerrado, once a particular entity is now classed as heavy or closed Cerrado, typical Cerrado and sparse Cerrado. In the first instance, heavy or closed Cerrado covers a redundant meaning, because cerrado, etymologically, means closed. This redundancy results from this fundamental oblivion for the instantiation of semantic change and for the establishment of the new meanings in the conceptual apparatus of the language users. In the third instance, the term sparse Cerrado loses contact with the etymological meaning of the terminology that named the vegetation, and therefore this term is re-signified from closed Cerrado, making it a counterpoint of meaning and naming another aspect of the vegetation. What has occurred, exemplified perhaps by the use of typical Cerrado, is that Cerrado is now defined by location and existence - a particular biome in Brazil - than in reference to the physiognomic characteristics in earlier naming. It is notable that publicly available online sources (Wikipedia, for example) and scientific papers (eg. de Sousa et al, 2015) make no reference to the original meaning or use the word closed to describe the biome.

Without the same adoption of modifiers, the use of Vereda to indicate the geographic landscape has been adopted without reference to the understanding of path. Without anchoring 
to the original meanings, the term may find the same freedom to re-classify and denote some features of this biome subsystem, particularly if human activity changes the soil and water quality over particular regions. The word that has already followed a metonymic track from horse to Brazilian landscape may further provide new experiences to name.

\section{CONCLUSION}

This study highlighted the process of instantiation of meaning and the subsequent semantic changes that the lexical items cerrado and vereda underwent, forms that designate in the present synchrony the Cerrado biome and its subsystem, Vereda, particularly in accounting for the use of metaphor and metonymy in the way humans name experience. As humans have experienced new worlds, they draw on their current lexicon in idiosyncratic ways - how some thing looks, how something feels - and ascribe meaningful words, lost through use and time. However, since linguistic sign is an arbitrary designation, it lacks the internal strength to retain its identity. Therefore, it becomes exposed to all sorts of changes, and once a lexical item passes into the time domain, it becomes its main indicator of stability and change.

Studying the history of a word provides the means to perceive both the uniqueness of its morph-phonological and semantic constitution and its relation to the object it designates. Understanding the functioning of these processes, presents itself at first as an intriguing puzzle, but whose pieces gradually reveal themselves and highlight the internal logic of lexical creation, as well as its semantic motivations in the process of naming an object in the world, as well as its subsequent changes of meaning. It is no doubt the case that the language user does not make such a metalinguistic reflection on the origin and motivation of names, especially when it concerns a lexical item already crystallized in Portuguese language as it is the case under analysis. However, without such study of the meaning surrounding a word in a current synchrony of a linguistic community gives rise to the illusion that it had always been there, meaning and describing the object of designation.

The words cerrado and vereda have their individual histories and singular constitutive meanings paths. Adopted into scientific discourse, they will continue to be re-defined as that which they define change and development. Such is the case with much of our languages, as original meanings are obscured and new ways of defining and understanding human activity emerge. Metaphor and metonymy will continue to provide conceptual resources for us to name the world.

\section{REFERENCES}

Barbosa, A. S. (2015). O Cerrado está extinto e isso leva ao fim dos rios e dos reservatórios de água. Retrieved May 26, 2018 http://www.jornalopcao.com.br/entrevistas/o-cerradoesta-extinto-e-isso-leva-ao-fim-dos-rios-e-dos-reservatorios-de-agua-16970/

Barnden, J. A. (2010). Metaphor and metonymy: Making their connections more slippery. Cognitive linguistics. 21(1), 1-34.

Barcelona, A. (Ed.). (2003). Metaphor and metonymy at the crossroads: A cognitive perspective. Berlin: Mouton de Gruyter.

Díaz-Vera, J. E. (2014). From Cognitive Linguistics to Historical Sociolinguistics: The evolution of Old English expressions of shame and guilt. Cognitive Linguistic Studies. $1(1), 55-83$.

Ferreira, A. B. O. (2004). Novo Dicionário Aurélio da Língua Portuguesa. Curitiba: Positivo. Fiorin, J. L. (2014). Figuras de retórica. São Paulo: Contexto.

Kos, P. (2019). Metaphor and metonymy as a means of economy of expression. SKASE Journal of Theoretical Linguistics. 16(1), 146-161 
Lakoff, G. (1987). Women, fire, and dangerous things: what categories reveal about the mind. Chicago: University of Chicago Press.

Lakoff, G. \& Johnson, M. (1980). Metaphors we live by. Chicago: University of Chicago Press. Labov, W. (1994). Principles of linguistic change: Internal Factors. Cambridge \& Oxford: Blackwell Publishers Inc.

Löfgren, A. (1896). Ensaio para uma distribuição dos vegetais nos diversos grupos florísticos no Estado de São Paulo. São Paulo: [s.n.], 5-47.

Marra, D. \& Milani, S. E. (2013). Reflexões acerca da noção de língua como uma instituição social em William D. Whitney. Cadernos do IL. 46, 129-147.

Martius, C. F. P. (1938). Viagem pelo Brasil 1817 - 1820. v. II. São Paulo: Edições Melhoramentos.

Martius, C. F. P. (1943[1824]). A fisionomia do reino vegetal do Brasil. Curitiba: Arquivos do Museu Paranaense. 3, 239-271.

Musolff, A. (2012). The study of metaphor as part of critical discourse analysis. Critical Discourse Studies. 9(3), 301-310.

Radden, G. (2000). How metonymic are metaphors. In Barcelona, A. (Ed.). Metaphor and metonymy at the crossroads: A cognitive perspective (pp. 93-108). Berlin: Mouton de Gruyter.

Ribeiro, J. F \& Walter, B. M. T. (2008). As principais fitofisionomias do Bioma Cerrado. In: Sano, S. M., Almeida, S. P., Ribeiro, J. F. (Eds.) Cerrado. Ecologia e Flora (pp. 151212). Brasília: Embrapa Cerrados.

Rio-Torto, G. (2014). Desafios em morfologia. História e (re)conhecimento. In: Mário Eduardo Viaro (Org.). Morfologia Histórica (p. 31-57). São Paulo: Cortez.

Rosa, J. G. (1956). Grande sertao: Veredas. Rio de Janeiro: José Olympio.

Rosa, J. G. (2003). João Guimarães Rosa. Correspondência com seu Tradutor Italiano Edoardo Bizzarri. Rio de Janeiro: Nova Fronteira.

Roth, W. (1998). A Semântica Histórica: um campo abandonado da Linguística?. Filologia e Linguística Portuguesa. 2, 61-79.

Saussure, F. (2006). Curso de linguística geral. São Paulo: Cultrix.

Silva, A. S. (2006). O mundo dos sentidos em português. polissemia, semântica e cognição. Coimbra: Almedina.

Silva, A. S. (1999). A semântica do verbo deixar. Uma contribuição para a abordagem cognitiva em semântica lexical. Lisboa: Fundação Calouste Gulbenkian e fundação para a ciência e tecnologia.

Sousa, R. F., Brasil, E. P. F.s, Figueiredo, C. C. \& Leandro, W. M. (2015). Soil organic matter fractions in preserved and disturbed wetlands of the cerrado biome. Revista Brasileira de Ciência do Solo. 39(1), 222-231.

Trask, R. L. (2011). Dicionário de Linguagem e Linguística. São Paulo: Contexto.

Viaro, M. E. (2011). Etimologia. São Paulo: Contexto.

Viaro, M. E.; Ferreira, M. \& Guimarães-Filho, Z. (2014). Derivação ou terminação: limites para a semântica, lexicologia e morfologia históricas. In: M. E. Viaro (Org.). Morfologia Histórica (pp. 58-105). São Paulo: Cortez.

Villalva, A. \& Silvestre, J. P. (2014). Introdução ao estudo do léxico. Descrição e análise do português. Petrópolis: Vozes.

Warning, E. (1973[1892]). Lagoa Santa. A vegetação de cerrados brasileiros. São Paulo: EDUSP \& Belo Horizonte: Itatiaia.

Whitney, W. D. (1884[1867]). Language and the Study of Language. Twelve Lectures on the Principles of Linguistic Science. London: N. Trubnek \& Co., Ludgate Hill. 


\section{ABOUT THE AUTHORS}

Daniel Marra (Ph.D) is Lecturer at Federal Institute of Tocantins, Brazil. His interests are in Philosophy of Linguistics, Sociolinguistics and Lexicology. From 2018 to 2019, he was Visiting Scholar at the Department of Linguistics of The University of Sydney, Australia.

Marie Quinn (Ph.D) is Lecturer in TESOL and Applied Linguistics at the University of Technology Sydney, Australia. Her interests are in Sociolinguistics and educational linguistics, particularly in multilingual classrooms.

Luiz Arthur Blamires is a Master student at the Université de Paris (Paris Diderot), France. His interests are in Computational Linguistics and Lexicology. 